\title{
Enhancement of protozoan pathogen Perkinsus marinus infections in American oysters Crassostrea virginica exposed to the chemical carcinogen n-nitrosodiethylamine (DENA)*
}

\author{
James T. Winstead, John A. Couch
}

US Environmental Protection Agency, Environmental Research Laboratory, Gulf Breeze, Florida 32561, USA

\begin{abstract}
American oysters Crassostrea virginica exposed to high concentrations (600 $\mathrm{mg} \mathrm{l}^{-1}$ ) of $\mathrm{n}$ nitrosodiethylamine (DENA) during winter (February to May) showed significant enhancement of an epizootic apicomplexan parasite, Perkinsus marinus. The parasite reproduced and caused atypical lesions in exposed oysters in water temperatures at its lower range $\left(20^{\circ} \mathrm{C}\right)$. The reasons for this enhancement are not clear but may reflect damage to the oysters' nonspecific, cellular defense mechanisms by the DENA without concomitant negative effects on the parasite.
\end{abstract}

\section{INTRODUCTION}

Perkinsus marinus, formerly Dermocystidium marinum, is epizootic in American oysters Crassostrea virginica and a significant cause of mass mortality in Gulf coast and mid-Atlantic estuaries of the USA (Mackin 1951, Ray 1954 a,b, Dunnington 1956, Mackin \& Hopkins 1962, Lauckner 1983, Sparks 1985). The taxonomy, morphology and pathology of $P$. marinus have been extensively reviewed (Perkins 1976, Levine 1978, Lauckner 1983, Sparks 1985).

Previous investigators indicated that Perkinsus marinus infections in oysters are enhanced by temperatures above $20^{\circ} \mathrm{C}$ (Mackin 1962, Quick \& Mackin 1971, Andrews 1976), salinities above 15\% (Mackin 1956, Scott et al. 1985), close proximity or crowding (Mackin 1962, Andrews 1965, 1979), and spawning state of the oysters (Ray 1954a, Andrews \& Hewatt 1957, Mackin 1962, Sinderman 1970). Scavengers (Hoese 1964) and ectoparasitic snails (White et al. 1987) which feed on oysters infected with the parasite may act as vectors in transmitting the disease to other oysters.

This paper reports the first experimentally induced enhancement of Perkinsus marinus in Crassostrea vir- Contribution No. 645 of the Environmental Research La-
boratory ginica, with the chemical carcinogen DENA. Histopathological consequence of the infections and possible reasons for the enhancement phenomenon are also discussed.

\section{MATERIALS AND METHODS}

American oysters Crassostrea virginica were collected from East Bay, Santa Rosa County, Florida, USA, in November 1986 and held in flow-through seawater tanks until experiments were begun in February 1987. A baseline sample (50 oysters) was taken at the collection site and 17 individuals were sampled for histological examination $3 \mathrm{~d}$ prior to tests. Exposed and control oysters were held in static $12 \mathrm{l}$ aquaria during each test. No attempt was made to feed exposed or control oysters during tests. Temperature and salinity were maintained at $20^{\circ} \mathrm{C}$ and $20 \%$, respectively. Experimental oysters were exposed to $600 \mathrm{mg} \mathrm{l}^{-1}$ of $\mathrm{n}$-nitrosodiethylamine (Sigma N0258) for up to $28 \mathrm{~d}$.

Four separate tests were conducted over a $14 \mathrm{wk}$ period (Tables 1 and 2). Test 1 was designed to determine acute effects of high concentrations of the carcinogen on exposed oysters. Samples of 3 exposed and 2 control oysters were taken for histological examination at Days 1, 2, 4, 7, 11 and 14. Additionally, 4 exposed and 3 controls were taken when tests were 
Table 1. Crassostrea virginica. Results from tests exposing oysters to DENA $\left(600 \mathrm{mg} \mathrm{l}^{-1}\right)$. In Test 1,22 oysters were taken for histological examination during test $(+), 23$ survivors were transferred to clean seawater and held for 3 wk after test termination before histological examination $\left({ }^{*}\right)$

\begin{tabular}{|c|c|c|c|c|c|}
\hline Test & Date of test & No. exposed & Days exposed & No. left at test end & $\begin{array}{l}\text { Percent sampled } \\
\text { at test end with } \\
\text { Perkinsus marinus } \\
\text { enhancement }\end{array}$ \\
\hline 1 & Feb 87 & $45+$ & 27 & $23^{\circ}$ & 100 \\
\hline 2 & Mar 87 & 20 & 17 & 5 & 100 \\
\hline 3 & Apr 87 & 20 & 28 & 6 & 67 \\
\hline 4 & May 87 & 20 & 26 & 7 & 86 \\
\hline
\end{tabular}

Table 2. Crassostrea virginica. Control oysters from DENA exposure tests. In Test 1, 15 samples were taken during $27 \mathrm{~d}(+)$

\begin{tabular}{|c|c|c|c|c|c|}
\hline Test & Date of test & No. of controls & Days held & No. left at test end & $\begin{array}{l}\text { Percent sampled } \\
\text { at test end with } \\
\text { Perkinsus marinus } \\
\text { enhancement }\end{array}$ \\
\hline 1 & Feb 87 & $25+$ & 27 & 10 & 0 \\
\hline 2 & Mar 87 & 20 & 17 & 20 & 0 \\
\hline 3 & Apr 87 & 20 & 28 & 20 & 0 \\
\hline 4 & May 87 & 20 & 26 & 20 & 0 \\
\hline
\end{tabular}

terminated $(27 \mathrm{~d})$. Surviving exposed oysters (23 total) were transferred to clean seawater and histologically examined 3 wk later.

Tests 2,3 and 4 were conducted between March and May 1987 to verify the Perkinsus marinus enhancement observed in Test 1 . In each test, 20 oysters were exposed to the carcinogen and sampled for histological examination after mortalities were greater than $50 \%$. Test 2 was terminated after $17 \mathrm{~d}$ with 5 surviving test specimens and Tests 3 and 4 were terminated after 28 and $26 \mathrm{~d}$ with 6 and 7 survivors, respectively (see Tables 1 and 2). Control oysters were also sampled at the same time exposed oysters were taken.

Sampled oysters were grossly examined and $1 \mathrm{~cm}$ thick transverse cuts were taken across the digestive gland, fixed in Davidsons' fluid (Shaw \& Battle 1957) and embedded in Paraplast ${ }^{\circledR}$. Tissue was sectioned at $7 \mu \mathrm{m}$ and stained with Harris' hematoxylin and eosin (Luna 1968).

Fig. 1 illustrates the general experimental design used to evaluate Perkinsus marinus enhancement in oysters exposed to DENA. Microscopic quantification of $P$. marinus infections in test oysters was done to obtain relative prevalence/intensity values. The number of parasite stages per field (at $400 \times$ ) infecting the outer gut loop epithelia (Fig. 2) was quantified by

\footnotetext{
(i) Mention of trade names or commercial products does not constitute endorsement or recommendation for use
}

observing 6 microscopic fields on each of 10 slides prepared from control oysters and 10 each from exposed and baseline oysters. Values for respective groups of 10 slides were averaged to obtain the infection values. Light infections averaged 3 observable parasites per field, moderate infections averaged 16, and heavy infections averaged more than 170 .

\section{RESULTS}

Histological examination of baseline oysters sampled $3 \mathrm{~d}$ before tests showed all individuals with healthy digestive gland epithelia and vesicular connective tissue (VCT). Most individuals had light to moderate infections of Perkinsus marinus in gut epithelia concomitant with some hemocytic response to the pathogen but no severe histologic damage was observed (Fig. 3).

Results of the 4 tests are shown in Tables 1 and 2 . Experimental oysters in Tests 2, 3 and 4 began to have significant mortalities $17 \mathrm{~d}$ postexposure to DENA; only 18 individuals $(30 \%)$ survived when the tests were terminated (Table 1). In contrast, no control oysters died (Table 2). Histological examination of moribund or 'gaper' oysters indicated the probable cause of death to be heavy Perkinsus marinus infections. Examination of exposed and control oysters, after tests were terminated, showed very heavy infections of $P$. marinus in 
Figure 1. Experimental design used to study the effects of DENA exposures on oysters.

\begin{tabular}{|c|c|c|}
\hline Control & Baseline & Exposed \\
\hline Oysters not exposed & Histologically examined 3 days & Oysters exposed to \\
\hline to DENA, but main- & Defore tests to determine preva- & $600 \mathrm{mg} \mathrm{t}^{-1}$ of DENA \\
\hline tained in identical & lence and intensity of pathogen. & for 17 to 28 days \\
\hline holding tanks as & !1nco with light to moderate & (4 separate tests) \\
\hline exposed groups & infections concomitant with & \\
\hline
\end{tabular}

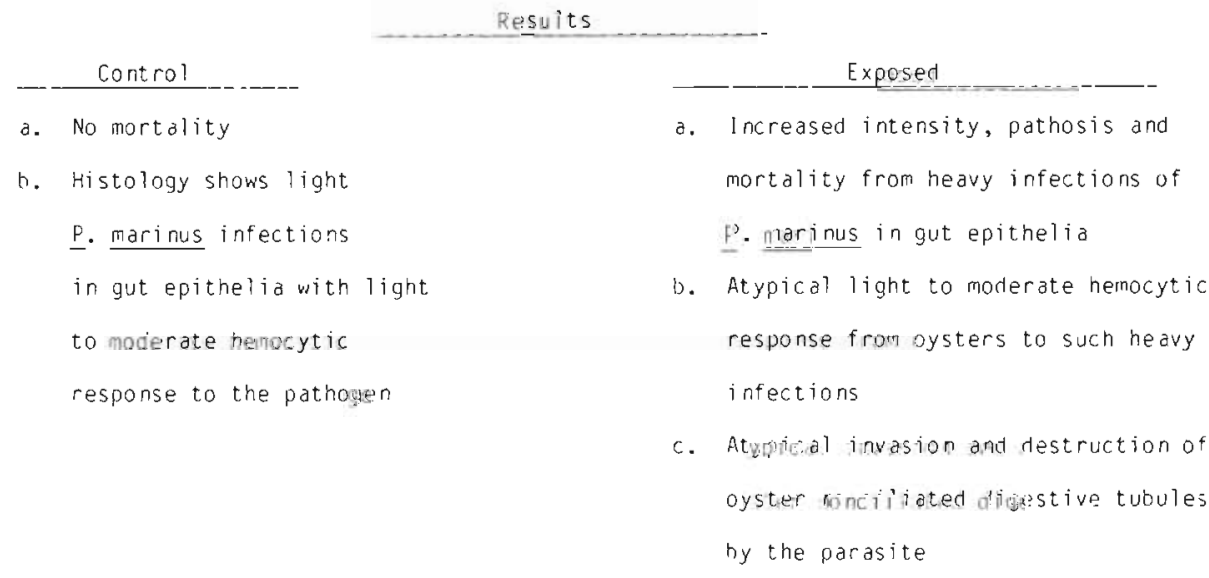

Results of nepuration

Histology of surviving DEMA-exposed oysters transferred to clean

seawater fur 3 weeks shows most oysters with light infections of

Fig. 1 Experimental design of methods used to evaluate results of DENA-exposed tests

- marinus in gut enithelia concomitant with ?ight to moderate

nemocytic respunse

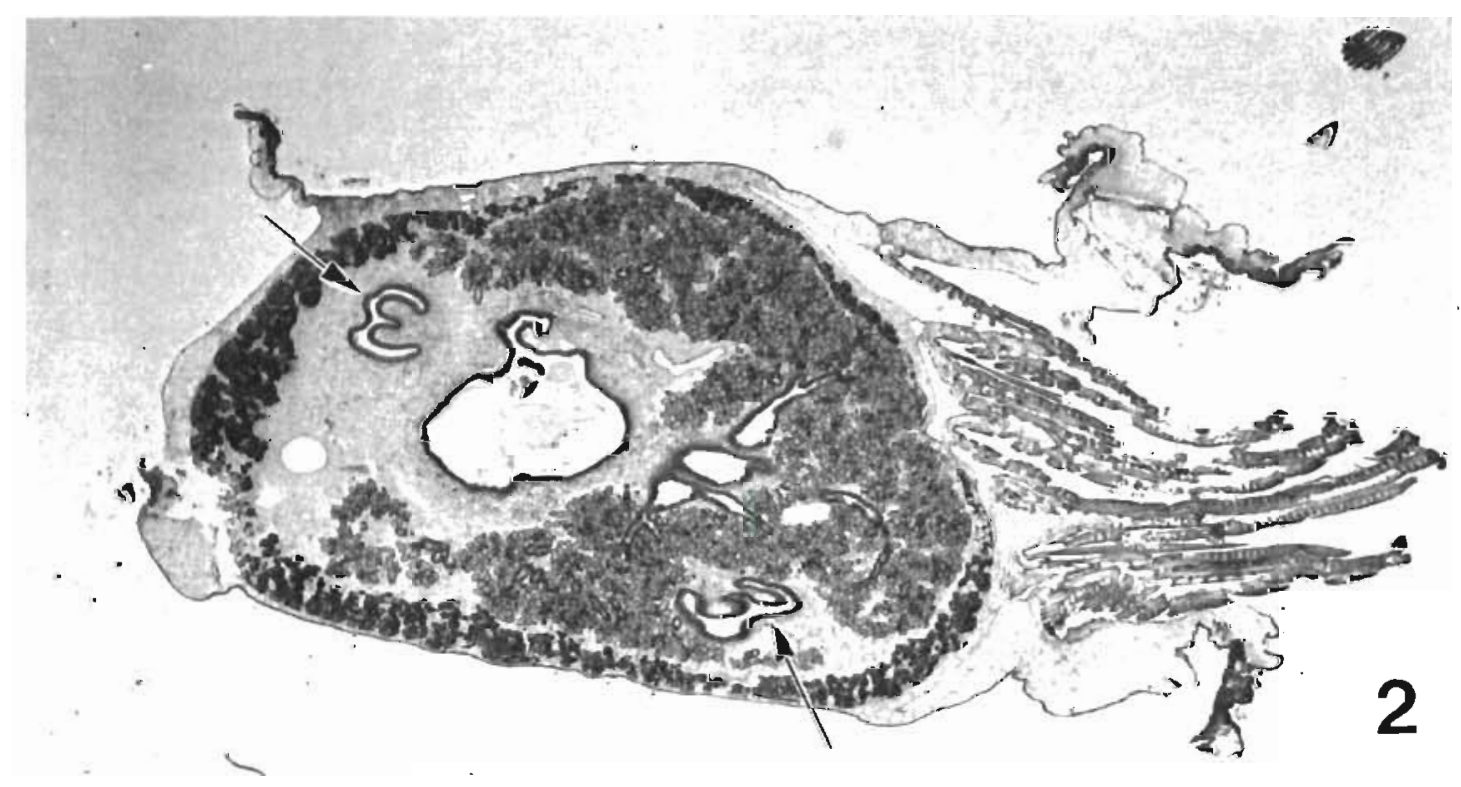

Fig. 2. Crassostrea virginica. Cross section of an oyster taken through the visceral mass just below the palps showing the general area examined. Note the 2 outer intestinal loops (arrows) used to determine microscopic quantification of Perkinsus marinus prevalence/intensity values (arrows). $(\times 7)$ 
gut epithelia from 15 of 18 (83\%) experimental oysters (Figs. 4 and 5) and only light infections in gut epithelia of controls (Fig. 6).
Test 1 had no mortalities in experimental or control oysters. Of 18 exposed and 14 control oysters histologically examined $14 \mathrm{~d}$ postexposure, $83 \%$ of exposed and
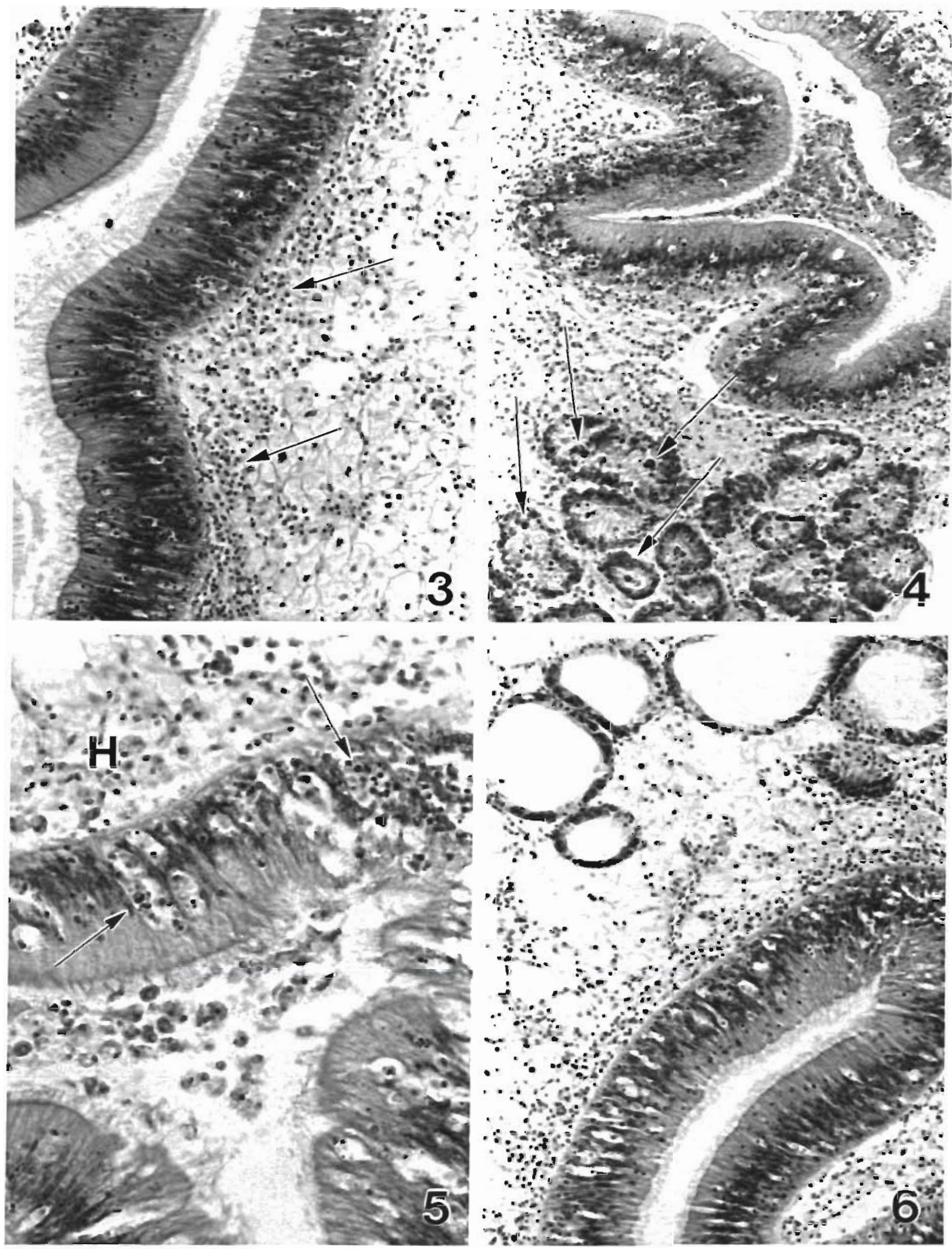
$100 \%$ of control oysters showed light infections with the parasite. After $27 \mathrm{~d}$, all exposed oysters sampled (4) showed heavy infections of Perkinsus marinus in gut epithelia identical to Tests 2, 3 and 4 (Figs. 4 and 5) while all controls had only light infections of the parasite (Fig, 6).

All exposed oysters with heavy Perkinsus marinus enhancement showed similar histopathological effects. A massive increase of uninucleate meronts and multinucleate schizonts in gut epithelia concomitant with sloughing of epithelia and pathogen into the digestive lumen was observed (Fig. 4). No significant hemocytic infiltration into gut epithelia or foci of these cells beneath the epithelial basement membrane was seen (Figs. 4 and 5). The lack of a significant hemocytic response to such heavy $P$. marinus infection in gut epithelia is atypical. Fig. 7 illustrates a typical hemocytic response in feral oysters with heavy infections of the pathogen in gut epithelia and should be compared with the hemocytic response in DENA-exposed oysters (Figs. 4 and 5). In addition, a massive invasion and replacement of nonciliated digestive tubule epithelia by meronts with no significant hemocytic response to the parasite were observed (Figs. 8 and 9). Control oysters with $P$. marinus infections in gut epithelia showed typical light to moderate hemocytic responses to the pathogen with localized foci of such cells beneath gut epithelial basement membranes (Fig. 6).

All test oysters showed diminished digestive tubule epithelia, which is normal in bivalves held in static aquaria without food for several weeks. Surviving oysters from Test 1, histologically examined 3 wk after transfer from DENA exposure aquaria to clean water, showed only light infections of Perkinsus marinus in gut epithelia and healthy nonciliated digestive tubules free of the parasite (Fig. 10).

A summary of data (Tables 1 and 2) from all tests shows that of 105 exposed oysters, $42 \quad(40 \%)$ died within an average of $24 \mathrm{~d}$ after tests began. Of 22 exposed oysters remaining alive and histologically examined at the end of tests, $19(86 \%)$ showed heavy infections of the pathogen. In contrast, no control oysters died or showed histological evidence of heavy Perkinsus marinus infections during or after tests (Table 2).

\section{DISCUSSION}

These tests were designed to determine acute toxicity of DENA to oysters for later carcinogen assay tests, and the Perkinsus marinus enhancement discovery was an ancillary observation. High concentrations of the carcinogen $\left(600 \mathrm{mgl}^{-1}\right)$ did not appear to induce the same acute histopathologic effects as reported for other bivalve molluscs exposed to nitrosamines. Examination of DENA-exposed oysters showed no congestion of hemolymph sinuses or branchial blood vessels by blood cells or necrotic lesions in VCT reported in Mytilus edulis exposed to $100 \mathrm{mgl}^{-1}$ of dimethylnitrosamine (DMN) for $14 \mathrm{~d}$ (Rasmussen 1982). Also, no focal hyperplasia of gut epithelia accompanied by nodular proliferations of basophilic cells described in Unio pictorum exposed to DMN or DENA $\left(400 \mu \mathrm{gl}^{-1}\right)$ for $4 \mathrm{wk}$ were observed (Khudoley \& Syrenko 1978). The reason oysters exposed to DENA in our tests did not show similar acute effects may reflect differences in species sensitivity or response potential. It may be that nitrosamines are not as toxic to post-spawn oysters in cool water temperatures as to other spawning bivalve species. Oysters have been shown to be more susceptible to xenobiotics during spawning when water temperatures are above $25^{\circ} \mathrm{C}$ (Scott \& Vernberg 1979, Scott et al. 1985).

Significant mortalities occurred in Tests 2, 3 and 4 but there were none in Test 1 . The reasons are not clear and may reflect a variation in tests.

Although some of the lesions of Perkinsus marinus infections or classic 'Dermo disease' described by earlier investigators were observed in exposed oysters, there were significant differences. Classic Dermo disease' begins as a chronic disorder and may take months to produce mortality in the host (Menzel \& Hopkins 1955). The enhancement phenomenon was acute and caused accelerated mortality in test oysters in less than $3 w k$. Histologic examination of oysters with the enhancement phenomenon showed some hemocytic response to $P$. marinus in gut epithelia and vesicular connective tissues of body and mantle, but the response was atypically light for such heavy infections of this parasite (compare Fig. 7 with Figs. 4 and 5). Heavy $P$. marinus infections in oysters are thought to

Figs. 3 to 6. Crassostrea virginica. Fig. 3. Baseline oyster $3 \mathrm{~d}$ before tests showing moderate Perkinsus marinus infection in gut epithelia with light hemocytic response beneath gut epithelia basement membrane (arrows). ( $\times 860$ ). Fig. 4. Typical heavy infection of $P$. marinus in gut epithelia of oysters exposed to DENA $\left(600 \mathrm{mg}{ }^{-1}\right)$ for 17 to $28 \mathrm{~d}$. Note sloughing of parasite and epithelia into gut lumen, moderate hemocytic response by the oyster and atypical invasion of the parasite into nonciliated digestive tubules (arrows). $(\times 860)$. Fig. 5. Higher magnification of P. marinus infection in oyster gut epithelia exposed to DENA $\left(600 \mathrm{mgl}^{-1}\right)$ for 17 to $28 \mathrm{~d}$. Note numerous parasite stages in gut epithelia (arrows) with a moderate hemocytic response (H) beneath the gut epithelial basement membrane. $(\times 1720)$. Fig. 6 . Control oyster from DENA exposure tests with a light infection of P. marinus in gut epithelia. A moderate hemocytic response to the pathogen concomitant with normal diapedesis by blood cells in gut epithelia is occurring due to starvation stress. Note diminished epithelia of nonciliated digestive tubules with no $P$. marinus invasion. (Compare with Figs. 4, 7, 8 and 9). $(\times 860)$ 


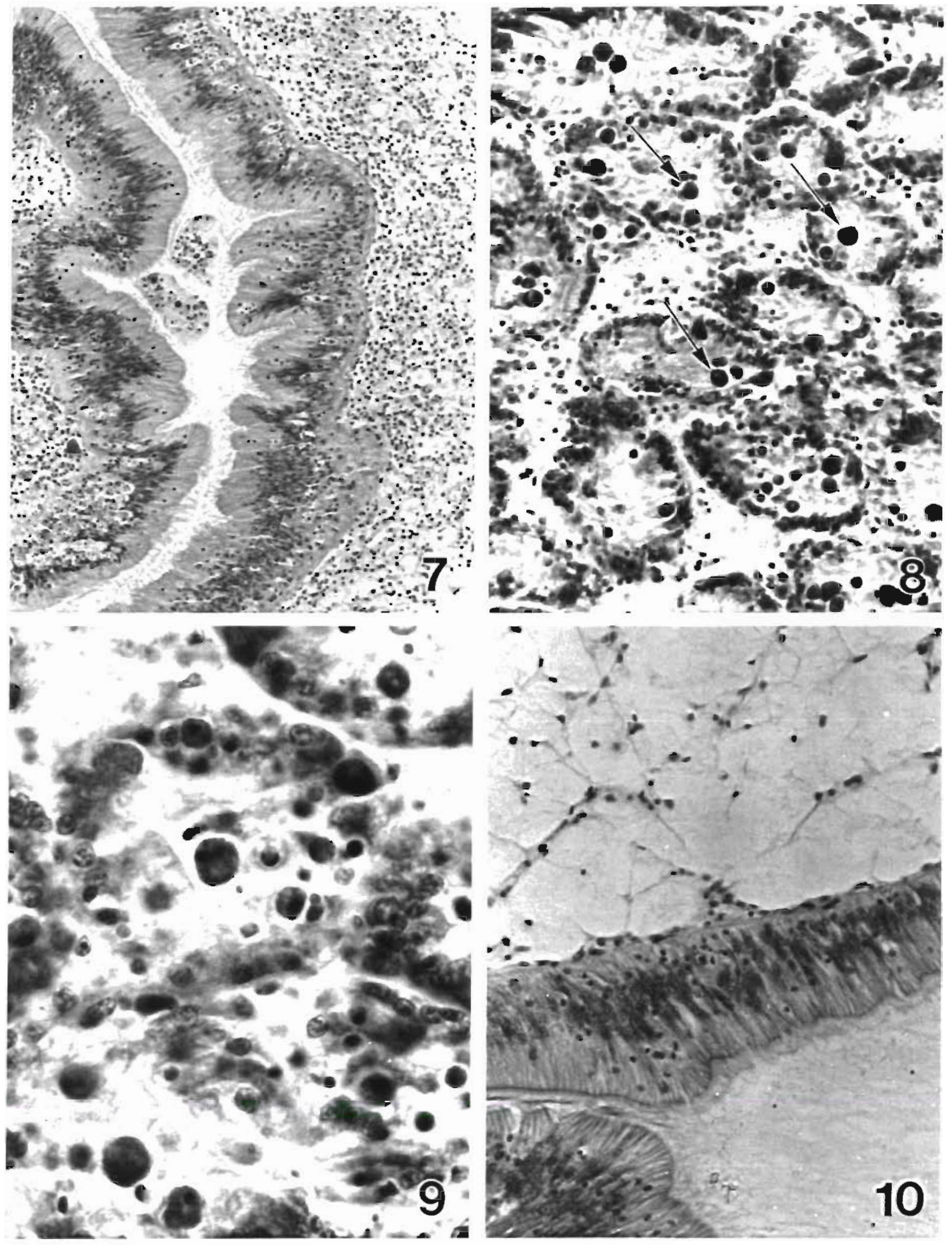

Figs. 7 to 10. Crassostrea virginica. Fig. 7. Typical heavy Perkinsus marinus infection of oyster gut epithelia. Note heavy hemocytic response and sloughing of parasite and gut epithelia into gut lumen. $(\times 860)$. Fig. 8 . Atypical invasion and destruction of nonciliated digestive tubules by $P$. marinus in oysters exposed to DENA (600 $\mathrm{mg} \mathrm{l}^{-1}$ ) within 17 to $28 \mathrm{~d}$ (arrows). ( $\left.\times 1720\right)$. Fig. 9 . Higher magnification of Fig. 8 showing definite parasite meronts in the epithelia and lumen of exposed oysters' nonciliated digestive tubules. $(\times 2400)$. Fig. 10. Gut epithelia of oysters exposed to DENA $\left.\left(600 \mu^{-1}\right)^{-1}\right)$ for $28 \mathrm{~d}$ and depurated in clean flowing seawater for $3 w k$. Note no parasites present in gut epithelia or hemocytic response by the oyster $(\times 860)$ 
cause mortality via systemic invasion and damaging blood sinuses (Mackin 1951, Sparks 1985) but this was not observed in DENA-exposed oysters. A striking difference between classic 'Dermo disease' and pathosis in exposed oysters was a massive invasion and destruction of nonciliated digestive tubule epithelia by the pathogen. This is atypical because nonciliated digestive tubules are not generally invaded and destroyed by $P$. marinus, like gut epithelia, but become necrotic due to destruction of supporting connective tissue and blood sinuses by the parasite (Mackin 1951, Perkins 1976, Sparks 1985).

All baseline oysters histologically examined before tests had light to moderate infections of the parasite in gut epithelia. This coincides with reports that the primary portal of entry is gut epithelia (Mackin 1951) and the pathogen can lie dormant in host tissue for months in water temperatures of $20^{\circ} \mathrm{C}$ or less (Hewatt \& Andrews 1954, Ray 1954 a, Mackin 1962, Quick \& Mackin 1971). Prevalence and intensity of infections increase linearly at temperatures above $18^{\circ} \mathrm{C}$ (Mackin \& Sparks 1962, Quick \& Mackin 1971), and the parasite does not readily multiply or cause significant pathosis in oysters below this temperature (Andrews \& Hewatt 1957, Andrews 1966). Thus, to date, temperature has been established as the most important environmental factor affecting virulence of Perkinsus marinus infections in oysters, with the most intense infections occurring above $25^{\circ} \mathrm{C}$ (Ray 1954 a, Mackin \& Sparks 1962, Ray 1966, Lauckner 1983). However, $P$ marinus did not remain dormant in DENA-exposed oysters but reproduced in large numbers causing pathologic damage and significant mortality $(86 \%)$ in temperatures of $20^{\circ} \mathrm{C}$. Conversely, the pathogen remained dormant in control oysters and did not multiply or become pathogenic at the same temperature.

It appears the DENA either directly or indirectly enhanced proliferation and lethality of Perkinsus marinus in exposed oysters since control oysters showed no signs of pathogen intensity enhancement and surviving oysters transferred to clean water showed no mortality or histological evidence of enhancement 3 wk after transfer

The reasons why Perkinsus marinus was able to multiply in tremendous numbers, infect tissues not generally invaded by the parasite, and become lethal in DENA-exposed oysters at temperatures below its normal pathologic range are not clear. It is possible the DENA 'causes a reduction in the effectiveness of internal defense mechanisms or modifies epithelial barriers and biochemical processes' in exposed oysters (Sinderman 1980). Bivalves do not possess humoral immune factors (antibodies) like vertebrates, but respond to pathogenic agents via nonspecific cellular mechanisms, such as leukocytic infiltration, phagocytosis, encapsulation and diapedesis (Sparks 1972, Cheng 1973). $P$. marinus does not reproduce readily or become intensely pathogenic in oysters below $20^{\circ} \mathrm{C}$ in natural environments; however, parasite meronts are capable of enlargement in thioglycollate media at $18^{\circ} \mathrm{C}$ (Ray 1954 a). Also, bivalves (Mytilus edulis) are capable of producing histologically detectable hemocytic responses to chemical injury in water temperatures below $15^{\circ} \mathrm{C}$ (Rasmussen 1982). Because control oysters showed no $P$. marinus enhancement and the carcinogen did not appear acutely toxic to test oysters, evidence suggests the DENA may have been toxic to the oysters' nonspecific cellular defense mechanisms. Prior studies indicate carcinogenic pesticides [such as organochlorines (DDT, Dieldrin) and carbamates (Urethan)] reduce phagocytic capacity and viability of macrophages and granular leukocytes in vertebrates (Exon et al. 1987). Also, similar enhancement of a pathogen (Baculovirus) in a crustacean (Penaeus duroarum) exposed to a polychlorinated biphenyl (Aroclor 1254) has been reported (Couch \& Nimmo 1974, Couch \& Courtney 1977). An earlier investigation of Crassostrea virginica exposed to chronic low levels of DDT, Toxaphene and Parathion (Lowe et al. 1971) may be relevant to the present study. The consulting pathologist, $\mathrm{Mr}$ Gilbert Pauley, reported heavy $P$. marinus infections in all exposed oysters examined, with atypically light hemocytic response to the pathogen. In contrast, few control oysters examined from the study were infected with the parasite. However, unlike the present study, the exposed oysters were sampled when salinities were very high $(29 \%)$ and water warm $\left(25^{\circ} \mathrm{C}\right)$.

If the resistance-compromising hypothesis is correct it would explain why the pathogen was capable of such tremendous proliferation and lethality in exposed oysters. However, it does not explain why the parasite was able to proliferate in such tremendous numbers at a temperature near its lower range. As already discussed, the most important factor which appears to control Perkinsus marinus infections in oysters is temperature. $P$. marinus is capable of enlargement in thioglycollate media at $18^{\circ} \mathrm{C}$ but has not been reported to be as active as observed in the DENA-exposed oysters in this study. Another possibility relating to the enhancement phenomenon may be that DENA is capable of stimulating the pathogen's growth directly. Few studies address the direct effects of chemicals on disease agents in aquatic animals (Esch et al. 1975, Lauckner 1983) and the present study indicates more research is needed. Prior investigators have suggested that certain diseases in economically important estuarine animals may be caused or enhanced by chemical pollutants in the environment (Sparks 1972, Couch \& Nimmo 1974, Fries \& Tripp 1976, Overstreet \& Howese 1977, Couch 
\& Courtney 1977, Sinderman 1980, Couch 1985, Couch \& Harshbarger 1985) even though there are few studies which directly link specific pollutants to specific diseases. The DENA enhancement of $P$. marinus infections in Crossostrea virginica appears to substantiate the thesis that chemical enhancement of certain pathogens can occur in some aquatic animals (Couch \& Nimmo 1974, Couch \& Courtney 1977, Couch \& Harshbarger 1985). This may be relevant in epizootiological areas where $P$. marinus causes the greatest mortalities in oysters since some studies indicate prevalence and intensity of some infections to be heavier in estuaries impacted with more chemical pollution (Couch 1985). We do not mean to imply that every host-pathogen/ parasite relationship will be umbalanced in favour of only the pathogen at the expense of the host. In certain cases, it is possible that the parasite may be equally or more vulnerable to chemical influence. Each potential chemical effector must be evaluated on a case-by-case basis (empirically) until more is known about their mechanisms of action.

The exact mechanisms for the Perkinsus marinus enhancement phenomenon are not understood, but it is possible that DENA may be toxic to the cells of the oysters nonspecific defense mechanisms, or be capable of stimulating the pathogen's growth directly. Because of the economic importance of Crassostrea virginica in epizootiological areas of $P$. marinus, further studies should be conducted to determine: (1) What nonspecific cellular defense mechanisms exist in oysters with the capacity to keep $P$. marinus pathogenicity suppressed in cold temperatures when this study shows the parasite can be very active in these temperatures? (2) Why is $P$. marinus atypically active and pathogenic in oysters in the presence of a stressing agent in water temperatures below its normal pathogenic range? (3) Is DENA affecting the pathogen's growth directly? (4) Are other xenobiotics capable of causing similar P. marinus enhancement in oysters in cold or warm water temperatures?

\section{LITERATURE CITED}

Andrews, J. D. (1965). Infection experiments in nature with Dermocystidium marinum in Chesapeake Bay. Chesdpeake Sci. 6: 60-67

Andrews, J. D. (1966). Oyster mortality studies in Virginia. $\checkmark$. Eplzootiology of MSX, a protistan pathogen of oysters. Ecology 47: 19-31

Andrews, J. D. (1976). Epizootiology of Dermocystidium marinum (Labyrinthomyxa marina) in. oysters. Proc. 1st Jnt. Colloq. Invertebr. Path. (Kingston, Canada), p. 172-174

Andrews, J. D. (1979). Oyster diseases in Chesapeake Bay Mar. Fish. Rev. 41:45-53

Andrews, J. D., Hewatt, W. G. (1957). Oyster mortality studies in Virginia. II. The fungus disease caused by Dermocystidium marinum in oysters of Chesapeake Bay. Ecol. Monogr. 27: 1-25
Cheng, T C. (1973). Immunity to parasites. In: Cheng, T C. (ed.) General parasitology. Academic Press, New York, p. $89-120$

Couch, J. A. (1985). Prospective study of infectious and noninfectious diseases in oysters and fishes in three Gulf of Mexico estuaries. Dis. aquat. Org. 1. 59-82

Couch, J. A., Courtney, L. (1977). Interaction of chemical pollutants and virus in a crustacean: a novel bioassay system. Ann. N. Y Acad. Sci. 298: 497-504

Couch, J. A., Harshbarger, J. C. (1985). Effects of carcinogenic agents on aquatic animals: an experimental overview. Environ. Carcinog. Revs. 3: 63-105

Couch, J. A., Nimmo, D. (1974). Detection of interactions between natural pathogens and pollutants in acquatic animals. In: Proc. Gulf Coast Regional Symp. Diseases of Aquatic Animals, Louisiana State University, Center for Wetland Resources, LSU-5G-74-05, p. 261-265

Dunnington, E. A. (1956). Oyster parasite distribution studies in Maryland Waters. Maryland Tidewater News 12: 1-3

Esch, G. W., Gibbons, J. W. Bourque, J. E. (1975). An analysis of the relationship between stress and parasitism. Am. Midl. Nat. 93: 339-353

Exon, J. H., Kerkvliet, N. I., Talcott, P. A. (1987). Immunotoxicity of carcinogenic pesticides and related chemicals Environ. Carcinog. Revs. C-5: 73-120

Fries, C., Tripp, M. R. (1976). Effects of phenol on clams. Mar Fish. Rev. 38: 10-11

Hewatt, W. G., Andrews, J. D. (1954). Oyster mortality studies in Virginia. I. Mortalities of oysters in trays at Gloucester point, York River. Tex. J. Sci. 6: 121-133

Hoese, H. D. (1964). Studies on oyster scavengers and their relation to the fungus Dermocystidium marinum. Proc. natl Shellfish. Ass. 53: 161-174

Khudoley, $V$ V., Syrenko, O. A. (1978). Tumor induction by $N$ nitroso compounds in bivalve molluscs Unio pictorum. Cancer Letters 4 : 349-354

Lauckner, G. (1983). Diseases of Mollusca: Bivalvia. In: Kinne O. (ed.) Diseases of marine animals, Vol. 2. Biologische Anstalt Helgoland, Hamburg, p. 477-961

Levine, N. D. (1978). Perkinsus gen. n. and other new taxa in the protozoan phylum Apicomplexa. J. Parasitol. 64: 549

Lowe, J. I., Wilson, P. D., Rick, A. J., Wilson, A. J. (1971) Chronic exposure of oysters to DDT, Toxaphene and Parathion. Proc natl Shellfish Ass. 61. 71-79

Luna, L. G. (1968). Manual of histologic staining methods of the Armed Forces Institute of Pathology, 3rd edn. McGraw Hill, New York, p. 258

Mackin, J. G. (1951). Histopathology of infection of Crassostrea virginica (Gmelin) by Dermocystidium marinum Mackin, Owen, and Collier Bull. mar Sci. Gulf Caribb. 1: 72-87

Mackin, J. G. (1956). Dermocystidium marinum and salinity. Proc. nati Shellfish Ass. 46: 116-128

Mackin, J. G. (1962). Oyster disease caused by Dermocystidium marinum and other microorganisms in Louisiana. Publs Inst. mar. Sci. Univ. Tex. 7: 132-229

Mackin, J. G., Hopkins, S. H. (1962). Studies on oyster mortality in relation to natural environments and to oll fields in Louisiana. Publs Inst. mar. Sci. Univ. Tex. 7: 1-131

Mackin, J. G., Sparks, A. K. (1962). A study of the effect on oysters of crude oil loss from a wild well. Publs Inst. mar. Sci. Univ. Tex. 7: 230-261

Menzel, R. W., Hopkins, S. H. (1955). The growth of oysters parasitized by the fungus Dermocystidium marinum and by the trematode Bucephalus cuculus. J. Parasitol. 41: $333-342$ 
Overstreet, R. M., Howse, H. D. (1977). Some parasites and diseases of estuarine fishes in polluted habitats of Mississippi. Ann. N. Y Acad. Sci. 298: 427-462

Perkins, F. O. (1976). Dermocystidium marinum infection in oysters. Mar Fish. Rev. 38: 19-31

Quick, J. A., Mackin, J. G. (1971). Oyster parasitism by Labyrinthomyxa marina in Florida. Florida Dept. of Natural Resources, Marine Research Lab. Prof. Papers Series No. 131. $1-55$

Rasmussen, L. (1982). Light microscopical studies of the acute toxic effects of $\mathrm{N}$-nitrosodiethylamine on the marine mussel, Mytilus edulis. J. Invert. Pathol 39: 66-80

Ray, S. M. (1954a). Biological studies of Dermocystidium marinum, a fungus parasite of oysters. Rice Inst. Pam. Special Issues, November 1954, p. 1-114

Ray, S. M. (1954b). Experimental studies on the transmission and pathogenicity of Dermocystidium marinum, a fungus parasite of oysters. J. Parasitol. 40: 235

Ray, S. M. (1966). Cycloheximide inhibition of Dermocystidium marinum in laboratory stocks of oysters. Proc. natl Shellfish. Ass. 56: 31-36

Scott, G. I., Vernberg, W. B. (1979). Seasonal effects of chlorine produced oxidants on the growth, survival and physiology of the American oyster, Crassostrea virginica (Gmelin). In: Vernberg, W. B. (ed.) Marine pollution: functional responses. Academic Press, New York, p. 501-516

Scott, G. I., Oswald, E. O., Sammons, T I., Baughman, D. S., Middaugh, D. P. (1985). Interactions of chlorine-produced oxidants, salinity, and a protistian parasite in affecting lethal and sublethal physiological effects in the Eastern or American Oyster In: Jolley, R. L., et al. (ed.) Water chlorination: chemistry, environmental impact and health effects; Vol.5. Lewis Publishers, Inc., Chelsea, Michigan, p. $463-480$

Shaw, B. L., Battle, H. I. (1957). The gross and microscopic anatomy of the digestive tract of the oyster Crassostrea virginica (Gmelnn). Can. J. Zool. 35: 325-347

Sinderman, C. J. (1970). Bibliography of diseases and parasites of marine fish and shellfish (with emphasis on commercially important species). Tropical Atlantic Biological Laboratory, Informal Report No. 11, p. 1-440

Sinderman, C. J. (1980). A critical examination of the relationships between pollution and disease. Int. Counc. Explor Sea (ICES), Special Meeting on Diseases of Commercially Important Marine Fish and Shellfish (Copenhagen, 1980) No. 53

Sparks, A. K. (1972). Invertebrate pathology Noncommunicable diseases. Academic Press, New York, p. 1-382

Sparks, A. K. (1985). Protozoan diseases. In: Synopsis of invertebrate pathology: exclusive of insects. Elsevier Science Publishers B. V., New York, p. 239-311

White, M. E., Powell, E. N., Ray, S. M., Wilson, E. A. (1987). Host-to-host transmission of Perkinsus marinus in oyster (Crassostrea virginica) populations by the ectoparasitic snail Boonea impressa (Pyramidellidae). J. Shellfish Res. 6: 1-5 